\title{
Increase in the amount of fetal lymphocytes in maternal blood during pregnancy
}

\author{
M KIRSCH-VOLDERS, E LISSENS-VAN ASSCHE, AND C SUSANNE \\ From the Vrije Universiteit Brussel, Laboratorium voor Antropogenetika, Pleinlaan 2, F4, 1050 Brussel, \\ Belgium
}

SUMmARY The presence of male fetal lymphocytes in the maternal blood of 18 pregnant women (15 primigravidae and three who had had previous pregnancies) was analysed by counting quinacrine positive $\mathrm{Y}$ bodies in interphases or $\mathrm{Y}$ chromosomes in metaphases.

Counts were also performed on a control population of ten young women who had never been pregnant and on another control population of seven men to test the efficiency of the staining technique used.

After completion of the calculations, comparison of the results with the sex of the newborn babies showed a correct sex prediction of $83 \%$ by interphase scoring and of $89 \%$ by metaphase scoring.

The lymphocyte transfer from fetus to mother has already started by the tenth week of pregnancy, and the percentage of fetal cells present in the bloodstream of a pregnant woman increases with the duration of the pregnancy.

The transfer of blood cells between mother and fetus in man is an established fact. Schröder ${ }^{1}$ estimated, using immunofluorescent techniques, that one fetal erythrocyte is present for every 50000 maternal erythrocytes in maternal blood. During the first trimester of pregnancy this transfer from the fetus to the mother takes place in only $10 \%$ of mothers; later on in the pregnancy this increases to $40 \%$ of the mothers. ${ }^{2-9}$ These cells are viable for about 200 days if the blood groups of mother and child are compatible.

The presence of maternal erythrocytes in fetal blood is described by different authors ${ }^{10-13}$; these erythrocytes represent between 1 to $10 \%$ of the total fetal blood volume but disappear quickly after birth (4 days). ${ }^{13}$

The transfer of lymphocytes from the fetus to the mother was studied by analysing the presence of male cells in maternal blood either by counting the number of acrocentrics without banding on metaphase cells ${ }^{14-16}$ or by scanning $Y$ positive interphases after $Q$ banding. ${ }^{17-19}$ The average frequency of fetal lymphocytes present in maternal blood was shown to be one fetal lymphocyte in 500 to 1000 maternal lymphocytes. These cells are sometimes present 3 to

Received for publication 23 October 1979
5 years after delivery and may thus interfere with fetal cells of following pregnancies. The presence of maternal lymphocytes in fetal blood, however, seems to be relatively rare (about $0.07 \%$ maternal lymphocytes in $1 / 10$ of the children). ${ }^{20}$

Many problems related to this cell transfer remain unsolved. How does transfer occur? When does this transfer start? What about immunological tolerance? This work presents a transverse analysis (from 6 to 40 weeks' gestation) and a tentative longitudinal (two blood samples per pregnancy) analysis of the frequency of fetal lymphocytes in the blood of primigravidae by quinacrine staining of the $Y$ chromosome in interphase and metaphase cells.

\section{Material and methods}

\section{SELECTION OF BLOOD SAMPLES}

Peripheral blood was collected from three groups: (1) a test population made up of 18 pregnant women who had not had a male child before and whose history of spontaneous abortions was checked. Gestation time was expressed in weeks after last menstruation. Each woman was examined once, twice, or three times; (2) a control population made up of ten young women who had never been pregnant; and (3) another control population made up of 
seven men. These cells were needed to estimate the exact efficiency of the $\mathrm{Y}$ detecting technique used.

\section{DETECTION OF Y CHROMOSOMES}

Peripheral lymphocytes were cultured for 48 hours and prepared by the method of Moorhead et al. ${ }^{21}$ The slides with cells collected from these cultures were hypertonically treated in a $\mathbf{Q}$ buffer (citric acid $0.05 \mathrm{~mol} / \mathrm{l}, \mathrm{Na}_{2} \mathrm{HPO}_{4} 0.1 \mathrm{~mol} / \mathrm{l}, \mathrm{pH} 4 \cdot 1$ ) for 7 minutes and stained for 8 minutes in a quinacrine dihydrochloride solution $(100 \mathrm{\gamma} / \mathrm{ml})$ prepared in the same $Q$ buffer. After soaking again for 7 minutes in the $\mathbf{Q}$ buffer, the slides were mounted in the $\mathbf{Q}$ buffer and observed by fluorescence microscopy (Zeiss microscope with a mercury lamp illumination excitation filter: BP 450-490; barrier filter: LP 520). The test and the two control populations were analysed separately.

For each of the test and two control populations, the number of $Y$ bodies was counted in 5000 interphase nuclei and the presence of a $\mathrm{Y}$ chromosome in 1000 metaphase cells. The sex of the new- borns was unknown until all calculations were

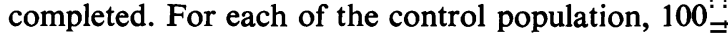
metaphases and 300 interphases were examined.

\section{Results and discussion}

\section{PRESENTATION OF INDIVIDUAL RESULTS} (FALSE POSITIVES AND FALSE NEGATIVES)

The results are shown in tables 1,2 , and 3. Table $1_{-}^{\infty}$ shows that with the number of interphases and. metaphases counted it is possible to see clear dif- $\overrightarrow{\vec{H}}$ ferences between pregnancies carrying male and $\omega$ female fetuses. However, false positives (case No $18 \overline{3}$ and 22) were scored for interphases in two of 18. pregnancies, probably because of unknown earlier $\vec{v}$ pregnancies or through misinterpretation. False negatives were scored for the interphases of oneo pregnancy which resulted in a male (No 14) and for the metaphases of two which resulted in a male? (No 19 and 59). These errors cannot have resulted from non-fluorescent $Y$ chromosomes since they werec all detectable either in metaphase or in interphase.

TABLE 1 Frequencies of $Y$ bodies in interphases and metaphases of the test population

\begin{tabular}{|c|c|c|c|c|c|c|c|c|c|c|}
\hline \multirow[t]{2}{*}{ Code No } & \multirow{2}{*}{$\begin{array}{l}\text { Age of } \\
\text { mother } \\
(y r)\end{array}$} & \multirow{2}{*}{$\begin{array}{l}\text { Earlier } \\
\text { pregnancies }\end{array}$} & \multirow{2}{*}{$\begin{array}{l}\text { Gestation } \\
\text { time at } \\
\text { sampling }\end{array}$} & \multicolumn{3}{|c|}{ Interphases } & \multicolumn{3}{|c|}{ Metaphases } & \multirow{2}{*}{$\begin{array}{l}\text { Sex of } \\
\text { child at } \\
\text { birth }\end{array}$} \\
\hline & & & & $\begin{array}{l}\text { Without } \\
Y\end{array}$ & $\underset{Y}{\text { With }}$ & $\%$ & $\begin{array}{l}\text { Without } \\
Y\end{array}$ & $\underset{Y}{\text { With }}$ & $\%$ & \\
\hline 18 & 19 & - & $\begin{array}{r}8 \\
18\end{array}$ & $\begin{array}{l}4999 \\
4999\end{array}$ & 1 & $\begin{array}{l}0.02 \\
0.02\end{array}$ & $\overrightarrow{1000}$ & $=$ & $\overline{0}$ & $\mathbf{F}$ \\
\hline \multirow[t]{2}{*}{22} & \multirow{2}{*}{18} & \multirow{2}{*}{-} & 7 & 4999 & 1 & 0.02 & 1000 & - & 0 & \multirow{2}{*}{ Twin FF } \\
\hline & & & 17 & 5000 & 0 & 0 & 1000 & - & 0 & \\
\hline \multirow[t]{2}{*}{27} & \multirow[t]{2}{*}{17} & \multirow{2}{*}{-} & 18 & 5000 & $\mathbf{0}$ & $\mathbf{0}$ & 630 & - & 0 & \multirow{2}{*}{$\mathbf{F}$} \\
\hline & & & $\begin{array}{l}32 \\
16\end{array}$ & $\begin{array}{l}5000 \\
5000\end{array}$ & $\begin{array}{l}0 \\
0\end{array}$ & $\begin{array}{l}0 \\
0\end{array}$ & $\begin{array}{r}1000 \\
320\end{array}$ & $=$ & $\begin{array}{l}0 \\
0\end{array}$ & \\
\hline \multirow{2}{*}{$\begin{array}{l}37 \\
39\end{array}$} & 27 & 1 daughter & 21 & 5000 & 0 & 0 & 500 & 二 & $\begin{array}{l}0 \\
0\end{array}$ & $\mathbf{F}$ \\
\hline & 21 & - & 21 & 5000 & 0 & 0 & 983 & - & 0 & $\mathbf{F}$ \\
\hline \multirow{2}{*}{45} & \multirow{2}{*}{21} & \multirow{2}{*}{-} & 6 & 5000 & 0 & 0 & 730 & - & o & \multirow{2}{*}{$\mathrm{F}$} \\
\hline & & & 7 & 5000 & 0 & 0 & 1000 & - & 0 & \\
\hline 3 & 23 & - & $\begin{array}{l}12 \\
33\end{array}$ & $\begin{array}{l}5000 \\
4999\end{array}$ & $\begin{array}{l}0 \\
1\end{array}$ & $\begin{array}{l}0 \\
0.02\end{array}$ & $\overline{793}$ & $\overline{3}$ & $\overline{0.38}$ & $\mathbf{M}$ \\
\hline & & & 7 & 5000 & 0 & 0 & - & - & 0.38 & \\
\hline 4 & 22 & - & 28 & 4999 & 1 & 0.02 & 809 & 1 & 0.12 & $\mathbf{M}$ \\
\hline & & & 15 & 5000 & 0 & 0 & - & - & - & \\
\hline 14 & 23 & - & 27 & 5000 & 0 & 0 & 834 & 1 & 0.12 & $\mathbf{M}$ \\
\hline & & & 39 & 5000 & 0 & 0 & 1000 & 0 & 0 & \\
\hline 17 & 30 & 3 spontaneous & 8 & 5000 & 0 & 0 & - & - & - & $\mathbf{M}$ \\
\hline & & abortions & 19 & 4999 & 1 & 0.02 & 999 & 1 & $0 \cdot 10$ & \\
\hline 19 & 27 & - & $\begin{array}{l}18 \\
34\end{array}$ & $\begin{array}{l}5000 \\
4998\end{array}$ & $\begin{array}{l}0 \\
2\end{array}$ & $\begin{array}{l}0 \\
0.04\end{array}$ & -60 & - & $\overline{0}$ & $\mathbf{M}$ \\
\hline 23 & & & 10 & 4998 & 2 & 0.04 & 999 & 1 & $0 \cdot 10$ & $\mathbf{M}$ \\
\hline 23 & 28 & - & 26 & 4998 & 2 & 0.04 & 365 & 0 & & M \\
\hline 24 & 23 & - & 19 & 4998 & 2 & 0.04 & 999 & 1 & $0 \cdot 10$ & $\mathbf{M}$ \\
\hline & & - & 28 & 4999 & 1 & 0.02 & 1000 & 0 & 0 & \\
\hline 26 & 17 & - & 29 & 4997 & 3 & 0.06 & 600 & 0 & 0 & $\mathbf{M}$ \\
\hline & & & $\begin{array}{l}35 \\
12\end{array}$ & $\begin{array}{l}4996 \\
4998\end{array}$ & $\begin{array}{l}4 \\
2\end{array}$ & $\begin{array}{l}0.08 \\
0.02\end{array}$ & $\begin{array}{l}998 \\
354\end{array}$ & $\begin{array}{l}2 \\
0\end{array}$ & $\begin{array}{l}0 \cdot 20 \\
0\end{array}$ & \\
\hline 30 & 21 & - & 23 & 4998 & 2 & 0.02 & 622 & 1 & $0 \cdot 16$ & Twin FM \\
\hline & & & 29 & 4995 & 5 & 0.10 & 999 & 1 & $0 \cdot 10$ & \\
\hline 49 & 32 & 1 daughter & 37 & 4998 & 2 & 0.02 & - & - & - & $\mathbf{M}$ \\
\hline & & & 41 & 4998 & 2 & 0.02 & 300 & - & 0 & \\
\hline 59 & 17 & - & 38 & 4995 & 5 & $0 \cdot 10$ & 250 & - & 0 & $\mathbf{M}$ \\
\hline & & & $\begin{array}{l}40 \\
37\end{array}$ & $\begin{array}{l}4993 \\
4997\end{array}$ & $\begin{array}{l}7 \\
3\end{array}$ & $\begin{array}{l}0.14 \\
0.06\end{array}$ & $\overline{266}$ & 二 & $\overline{0}$ & \\
\hline 64 & 15 & - & 43 & 4996 & 4 & 0.08 & 997 & 3 & 0.30 & $\mathbf{M}$ \\
\hline
\end{tabular}


TABLE 2 Frequencies of $Y$ bodies in interphases and metaphases of the female control population

\begin{tabular}{|c|c|c|c|c|c|c|c|}
\hline \multirow[t]{2}{*}{ Code No } & \multirow{2}{*}{$\begin{array}{l}\text { Age } \\
(y r)\end{array}$} & \multicolumn{3}{|c|}{ Interphases } & \multicolumn{3}{|c|}{ Metaphases } \\
\hline & & $\begin{array}{l}\text { Without } \\
Y\end{array}$ & $\begin{array}{l}\text { With } \\
Y\end{array}$ & $\%$ & $\begin{array}{l}\text { Without } \\
Y\end{array}$ & $\begin{array}{l}\text { With } \\
Y\end{array}$ & $\%$ \\
\hline K 16 & 24 & 5000 & 0 & 0 & 889 & 0 & 0 \\
\hline K 17 & 19 & 5000 & 0 & 0 & 859 & 0 & 0 \\
\hline K 18 & 19 & 5000 & 0 & 0 & 1000 & 0 & 0 \\
\hline K 19 & 19 & 5000 & 0 & 0 & 650 & 0 & 0 \\
\hline K 20 & 19 & 4999 & 1 & 0.02 & 1000 & 0 & 0 \\
\hline K 21 & 19 & 5000 & 0 & 0 & 963 & 0 & 0 \\
\hline K 22 & 19 & 5000 & 0 & 0 & 1000 & 0 & 0 \\
\hline K 23 & 19 & 5000 & 0 & 0 & 790 & 0 & 0 \\
\hline K 24 & 19 & 5000 & 0 & 0 & 900 & 0 & 0 \\
\hline K 25 & 19 & 4999 & 1 & 0.02 & 1000 & 0 & 0 \\
\hline
\end{tabular}

TABLE 3 Frequencies of $Y$ bodies in interphases and metaphases of the male control population

\begin{tabular}{|c|c|c|c|c|c|c|c|}
\hline \multirow[t]{2}{*}{ Code No } & \multirow{2}{*}{$\begin{array}{l}\text { Age } \\
(y r)\end{array}$} & \multicolumn{3}{|c|}{ Interphases } & \multicolumn{3}{|c|}{ Metaphases } \\
\hline & & $\begin{array}{l}\text { Without } \\
Y\end{array}$ & $\begin{array}{l}\text { With } \\
Y\end{array}$ & $\%$ & $\begin{array}{l}\text { Without } \\
Y\end{array}$ & $\begin{array}{l}\text { With } \\
Y\end{array}$ & $\%$ \\
\hline M 1 & 23 & 120 & 180 & 60 & 19 & 81 & 81 \\
\hline M 2 & 21 & 125 & 175 & 58 & 17 & 83 & 83 \\
\hline M 3 & 45 & 134 & 166 & 55 & 25 & 75 & 75 \\
\hline M 4 & 25 & 144 & 156 & 52 & 19 & 81 & 81 \\
\hline M 5 & 25 & 146 & 154 & 51 & 11 & 89 & 89 \\
\hline M 6 & 32 & 117 & 183 & 61 & 18 & 82 & 82 \\
\hline M 7 & 23 & 141 & 159 & 53 & 12 & 88 & 88 \\
\hline
\end{tabular}

However, either low frequencies of fetal cells in maternal blood or insufficient amounts of cells counted may explain these errors.

Data obtained from the female control population (table 2) indicate that technique-dependent errors are extremely low; these errors result from erroneous interpretation since autosomal fluorescence was not observed in metaphases (false positives).

Blood samples from seven healthy adults were used as controls for staining. The mean percentage of interphases with detectable $\mathrm{Y}$ bodies was $56 \%$ ( 51 to $61 \%$ ) and the mean percentage of metaphases with detectable $\mathrm{Y}$ bodies was $83 \%(75 \%$ to $89 \%)$. These values agree well with previous observations. ${ }^{17}$

\section{ACCURACY OF SEX PREDICTION}

Accuracy of sex prediction based on interphases only (table 4), on metaphases only (table 5), or on both together (table 6) shows that the quinacrine staining used allows an $83 \%$ correct prediction by interphase scoring and an $89 \%$ correct prediction by metaphase scoring. It is also clear that the presence or the absence of a $\mathrm{Y}$ chromosome in metaphase is not always confirmed by $\mathrm{Y}$ bodies in interphase.

It might be considered that the analysis is acceptable only when both metaphases and interphases give the same results. In that case, our prediction is about $72 \%$ accurate $(13 / 18 \mathrm{~F})$. Our

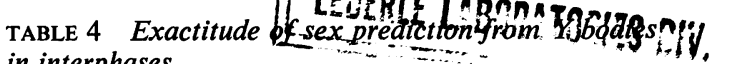
in interphases

\begin{tabular}{|c|c|c|c|c|}
\hline \multirow{2}{*}{$\begin{array}{l}\text { Mothers } \\
\text { examined }\end{array}$} & \multirow{2}{*}{$\begin{array}{l}\text { Sex of } \\
\text { child at } \\
\text { birth }\end{array}$} & \multicolumn{2}{|c|}{ Interphases studied } & \multirow{2}{*}{$\begin{array}{l}\% \text { exact } \\
\text { prediction }\end{array}$} \\
\hline & & Total & $\begin{array}{l}Y \text { positive } \\
\text { interphases }\end{array}$ & \\
\hline $\begin{array}{r}11 \\
1\end{array}$ & $\mathbf{M}$ & $\begin{array}{r}115000 \\
15000\end{array}$ & $\begin{array}{c}51(0.04 \%) \\
0(0 \%)\end{array}$ & \multirow{2}{*}{83} \\
\hline $\begin{array}{l}4 \\
2\end{array}$ & $\mathbf{F}$ & $\begin{array}{l}35000 \\
20000\end{array}$ & $\begin{array}{l}0(0 \%) \\
3(0.02 \%)\end{array}$ & \\
\hline
\end{tabular}

TABLE 5 Exactitude of sex prediction from $Y$ chromosomes in metaphases

\begin{tabular}{llccl}
\hline $\begin{array}{l}\text { Mothers } \\
\text { examined }\end{array}$ & $\begin{array}{l}\text { Sex of } \\
\text { child at } \\
\text { birth }\end{array}$ & Metaphases studied & $\begin{array}{l}\text { \% exact } \\
\text { prediction }\end{array}$ \\
\cline { 3 - 4 } & Total & $\begin{array}{l}\text { Y positive } \\
\text { metaphases }\end{array}$ & \\
\hline 10 & M & 12949 & $15(0 \cdot 12 \%)$ & \\
2 & F & 310 & $0(0 \%)$ & 89 \\
6 & 8163 & $0(0 \%)$ & \\
\hline
\end{tabular}

TABLE 6 Accuracy of sex prediction from interphase and metaphase counts together

\begin{tabular}{|c|c|c|c|c|c|}
\hline \multirow{2}{*}{$\begin{array}{l}\text { Sex of } \\
\text { child at } \\
\text { birth }\end{array}$} & \multicolumn{2}{|c|}{ Interphases } & \multicolumn{2}{|c|}{ Metaphases } & \multirow{2}{*}{$\begin{array}{l}\text { No of } \\
\text { mothers }\end{array}$} \\
\hline & $\begin{array}{l}\text { With } \\
\text { Y body }\end{array}$ & $\begin{array}{l}\text { Without } \\
Y \text { body }\end{array}$ & $\begin{array}{l}\text { With } Y \\
\text { chromo- } \\
\text { some }\end{array}$ & $\begin{array}{l}\text { Without } \\
\text { Y chromo- } \\
\text { some }\end{array}$ & \\
\hline \multirow{4}{*}{$\mathbf{F}$} & + & - & + & - & 0 \\
\hline & + & - & - & + & 2 \\
\hline & - & + & + & - & 0 \\
\hline & - & + & - & + & 4 \\
\hline \multirow{4}{*}{$\mathbf{M}$} & + & - & + & - & 9 \\
\hline & + & - & - & + & 2 \\
\hline & - & + & + & - & 1 \\
\hline & - & + & - & + & 0 \\
\hline
\end{tabular}

percentage of correct sex predictions agrees with those found by other authors, both in metaphase counts (Walknowska et al, ${ }^{14} 83 \%$; de Grouchy and Trébuchet, ${ }^{15} 67 \%$; Schindler et al, ${ }^{16} 38 \%$ ) and in interphase counts (Schröder and de la Chapelle, ${ }^{17}$ $71 \%$; Grosset et al, ${ }^{18} 86 \%$; Zilliacus et al, ${ }^{19} 72 \%$ ). Our results were favourably influenced by the following: the increase in the number of metaphases counted (1000 instead of 500), the use of banding instead of counting non-banded acrocentrics, and the selection of primigravidae (or mothers of girls).

\section{TRANSVERSE STUDY OF PRESENCE OF Y} CHROMOSOME DURING PREGNANCY

Fig 1 shows variations in the frequency of positive $Y$ bodies in fetal interphase cells in the blood of women pregnant with a male fetus. Fig 2 gives similar data for $\mathrm{Y}$ chromosomes in metaphase cells. 


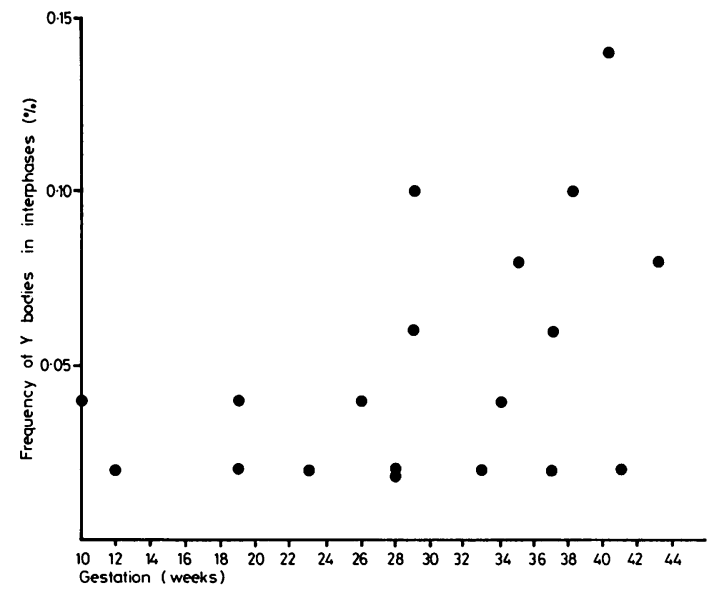

FIG 1 Variation of frequency of positive $Y$ bodies in interphase during pregnancy.

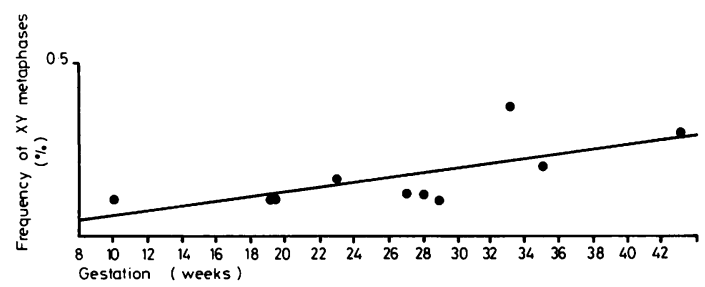

FIG 2 Variation of frequency of $X Y$ metaphases in the blood of pregnant women during pregnancy.

It is clear that both the frequency of $Y$ bodies in interphases and of $Y$ chromosomes in metaphases increase with gestation time.

Results obtained by other authors ${ }^{14-16}$ do not show this increase if taken separately. However, if all data obtained by other laboratories are collected, an increase of $\mathrm{Y}$ bodies and $\mathrm{Y}$ chromosomes during pregnancy is seen. We will thus consider that the number of Y-containing leucocytes increases with gestation time in women pregnant with a male fetus.

\section{LONGITUDINAL STUDY OF PRESENCE OF \\ Y CHROMOSOME DURING PREGNANCY}

Because of the lack of test material, the longitudinal analysis was feasible only for interphase counts and in only seven of the women pregnant with a male fetus. Fig 3 gives the observed frequencies of $Y$ bodies in interphase cells in two blood samples from each mother taken at different gestation times. Interpretation is difficult since the response seems to vary with gestation and mother. Moreover, some

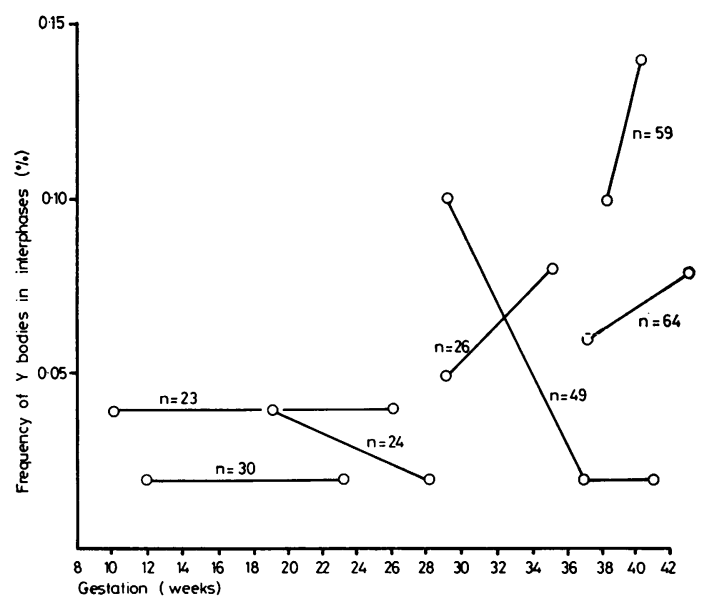

FIG 3 Longitudinal variation per mother of $Y$ body frequencies in interphase during pregnancy.

of the differences observed during one pregnancy may be the result of an insufficient amount of cells being analysed. More samples per mother are necessary to perform an accurate analysis.

\section{EARLIEST DETECTION OF MALE CELLS IN} PERIPHERAL BLOOD OF PREGNANT WOMEN Blood samples were taken as soon as 6 weeks after last menstruation; however, we were only able to detect positive staining $Y$ chromosomes at the earliest in a 10 week pregnancy.

This observation would signify that sex determination is possible earlier than is mentioned in other works: the 12 th week by Schindler $e t$ al, ${ }^{16}$ the 13th week by de Grouchy and Trébuchet, ${ }^{15}$ the 14th week by Grosset et al ${ }^{18}$ and by Walknowska et al, ${ }^{14}$ the 15 th week by Zilliacus et al, ${ }^{19}$ and the 16 th week by Schröder and de la Chapelle. ${ }^{17}$

Moreover, although fetal lymphopoiesis is classically considered to start at the 16th week, Playfair et $a l^{22}$ showed that lymphocytes are present in the fetus at the 8th week.

\section{REAL PERCENTAGE OF FETAL CELLS PRESENT} IN PERIPHERAL BLOOD OF PREGNANT WOMEN

The frequency of $\mathrm{Y}$ bodies in interphases varies between 0.02 to $0.14 \%$. If we now take into account the fact that, with our staining technique, only between 51 to $61 \%$ of the interphases of male peripheral blood cells react positively (table 3 ), the real percentage of fetal lymphocytes present in the peripheral blood of a pregnant woman would vary between 0.04 and $0.23 \%$. 
A similar calculation for the real percentage of $Y$ chromosomes present in metaphases of women pregnant with a male fetus shows a variation between 0.13 and $0.43 \%$. These results agree with observations made by Schindler et $a l^{16}$ on metaphases and by Schröder and de la Chapelle $^{17}$ on interphases. Walknowska et al $^{14}$ and de Grouchy and Trébuchet, ${ }^{15}$ however, found higher values $(0 \cdot 1$ to $2 \%$ ). This discrepancy may be because of the identification method used, since they neither had a correction factor for staining efficiency when counting small acrocentrics. On the other hand, Schindler et al, ${ }^{16}$ who also chose the acrocentric counting method, had results similar to ours.

\section{Conclusion}

From the data presented, two results must be underlined. Firstly, the lymphocyte transfer from fetus to mother has already started by the 10th week of pregnancy and, secondly, the percentage of fetal cells present in the bloodstream of a pregnant woman increases with the duration of the pregnancy. This shows, therefore, that by a harmless analysis of maternal blood the karyotype of male fetuses can be analysed earlier and more rapidly (one week) than by amniocentesis. Nevertheless, various disadvantages must be noted: firstly, there is only a 83 to $89 \%$ correct sex prediction; secondly, analysis is possible only for primigravidae; and finally no easy distinction between mother's and daughter's chromosomes can be made despite the fact that the latter is theoretically feasible using lateral asymmetry ${ }^{23}$ or other polymorphisms. ${ }^{2425}$

The use of this method for routine prenatal diagnosis will therefore depend on the improvement of biochemical and immunological techniques. Turunen et $a l^{26}$ distinguished fetal lymphocytes from maternal lymphocytes by a fluorescenceactivated cell sorter. Also it is possible that some mitogens might selectively stimulate fetal cells. ${ }^{26} 27$

As far as the function of the placenta is concerned, an observed increase of fetal lymphocytes during the pregnancy may signify any of the following: an increase in the amount or size of the transfer places in the placenta, an increase in the amount of cells transferred with the fetal blood volume, or an accumulation of consecutive haemorrhages. A longitudinal study based on more samples per pregnancy would give a better description of the phenomenon.

We thank the gynaecological team of Brugman Hospital (Professor Vokaer, Free University of Brussels) and especially Mrs F Bocken-D'Have and Mrs Van Hoey for kindly collecting blood samples.
We would also like to thank Mrs Paulus-Van Mechelen, Mrs G Plas, Mr R Wellens, and Mr F Raeymaekers for skilful technical help.

The valuable comments of Mrs G JungelsWinkler are gratefully acknowledged.

\section{References}

1 Schröder J. Transplacental passage of blood cells. J Med Genet $1975 ; 12: 230-42$.

${ }^{2}$ Zipursky A, Hull A, White FD, Istraels LG. Foetal erythrocytes in the maternal circulation. Lancet 1959; 1:451-2.

3 Wimhöfer H, Schneider J, Leidenberger F. Untersuchungen über die Einschwemmung fetaler Erythrozyten in den mütterlichen Krieslauf bei Spontangeburten und geburt shilflichen Eingriffen. Geburtshilfe Frauenheilkd 1962;22:589-97.

4 Clayton EM, Feldhaus WD, Whitacre FE. Fetal erythrocytes in the maternal circulation of pregnant women. Obstet Gynecol 1964;23:915-9.

5 Cohen F, Zuelzer WW, Gustafson DC, Evans MM. Mechanisms of isoimmunization. I. The transplacental passage of fetal erythrocytes in homospecific pregnancies. Blood 1964;23:621-46.

- Woodrow JC, Finn R. Transplacental haemorrhage. Br J Haematol 1966;12:297-309.

7 Cohen F, Zuelzer WW. Mechanisms of isoimmunization. II. Transplacental passage and postnatal survival of fetal erythrocytes in heterospecific pregnancies. Blood 1967;30:796-804.

${ }^{8}$ Betke K, Nierhaus K. Fetales Hämoglobin und fetale Erythrozyten im mütterlichen Blut während der Schwangerschaft und unter der Geburt. Munch Med Wochenschr 1968;110:509-16.

9 Bartsch FK. Fetale Erythrozyten in müterlichen Blut und Immunoprophylaxe der Rh-Immunisierung. Acta Obstet Gynecol Scand 1972; suppl 20.

10 Macris NT, Hellman LM, Watson RJ. The transmission of transfused sickle-trait cells from mother to fetus. Am J Obstet Gynecol 1958;76:1214-8.

11 Cohen F, Zuelzer WW. The transplacental passage cf maternal erythrocytes into the fetus. Am J Obstet Gynecol 1965;93:566-9.

12 Fischer K, Müller V. Zum Nachweiss mütterlicher Erythrocyten im Neugeborenenblut (Immunfluorescenzcenztechnik). Monatsschr Kinderheilkd 1967;115:147-8.

13 von Muralt G. Materno-fetale Blutung und 'respiratory distress syndrom'. Pad Fortbildungsk Praxis 1967;21: 90-102.

14 Walknowska J, Conte FA, Grumbach MM. Practical and theoretical implication of fetal/maternal lymphocyte transfer. Lancet 1969;1:1119-22.

15 de Grouchy J, Trébuchet C. Transfusion foeto-maternelle de lymphocytes sanguins et détection du sexe du foetus. Ann Genet (Paris) 1971;14:133-7.

16 Schindler AM, Graf E, Martin-du-Pan R. Prenatal diagnosis of fetal lymphocytes in the maternal blood. Obstet Gynecol 1972;40:340-6.

17 Schröder J, de la Chapelle A. Fetal lymphocytes in the maternal blood. Blood 1972;39:153-62.

18 Grosset L, Barrelet V, Odartchenko N. Antenatal fetal sex determination in maternal blood during early pregnancy. Am J Obstet Gynecol 1974;120:60-3.

19 Zilliacus R, de la Chapelle A, Schröder J, Tiilikainen A, Kohne E, Kleihauer E. Transplacental passage of foetal blood cells. Scand J Haematol 1975;15:333-8. 
20 Schröder J. Passage of leucocytes from mother to fetus. Scand J Immunol 1974;3:369-73.

21 Moorhead PS, Nowell PC, Mellman WJ, Battips DM, Hungerford DA. Chromosome preparations of leucocytes cultured from human peripheral blood. Exp Cell Res 1960;20:613-6.

22 Playfair JHL, Wolfendale MR, Kay HEM. The leucocytes of peripheral blood in the human fetus. $\mathrm{Br} J \mathrm{Hae}$ matol 1963;9:336-44.

23 Lin MS, Alfi OS. Variation in lateral asymmetry of human chromosome 1. Cytogenet Cell Genet 1978;21:243-50.

24 Balicek P, Zizka J, Skalska H. Variability and familial transmission of c-heterochromatin of human chromosomes evaluated by the method of linear measurement. Hum Genet 1978;42:257-65.
25 Viegas J, Salzano M. C-bands in chromosomes 1, 9, and 16 of twins. Hum Genet 1978;45:127-30.

26 Turunen $\mathrm{O}$, Lundqvist $\mathrm{C}$, de la Chapelle A. Fetal cells in the maternal blood: differential effects of mitogens on maternal and fetal lymphocytes. Excerpta Medica Int Cong Ser No 397, 1976;162-3.

27 Schröder J. Are fetal cells in maternal blood mainly B-lymphocytes? Scand J Immunol 1975;4:279-85.

Requests for reprints to Dr M Kirsch-Volders, Vrije Universiteit Brussel, Laboratorium voor $\overrightarrow{0}$ Antropogenetika, Pleinlaan 2, F4, 1050 Brussels, Belgium. 